ZOOLOGIA 29 (3): 195-202, June, 2012

doi: $10.1590 /$ S1984-46702012000300002

\title{
Population dynamics and reproductive strategy of Scolelepis goodbodyi (Polychaeta: Spionidae) in a subtropical atlantic beach
}

\author{
Luciana S. Dourado Leão1,3, Abílio Soares-Gomes², Tarso Costaํ \& Cinthya S. Gomes Santos² \\ 1 Programa de Pós-Graduação em Biologia Marinha, Universidade Federal Fluminense. Caixa Postal 100.644, \\ 24001-970 Niterói, RJ, Brazil. \\ 2 Departamento de Biologia Marinha, Universidade Federal Fluminense. Niterói, RJ, Brazil. \\ ${ }^{3}$ Corresponding author. E-mail: douradoleao@uol.com.br
}

\begin{abstract}
The population dynamics and reproductive strategy of the polychaete Scolelepis goodbodyi (Jones, 1962), were investigated between June 2009 and May 2010 at Manguinhos beach, southeastern, Brazil. A total of 9,242 individuals were collected. The density did not differ significantly from one month to another. The estimated values of the growth, recruitment, and mortality rates were studied using the width of the third setiger and the growth curves for the populations were adjusted by the Bhattacharya method $(L \infty=1.23, \mathrm{~K}=1.2$, mortality $=0.73)$. Two annual cohorts were identified in the period. Significant differences between males and females were observed in the population $\left(\chi^{2}=71.6, p<0.01\right)$ and between sexually defined and sexually indeterminate individuals $\left(\chi^{2}=158.4, p<0.01\right)$. Five stages of gonadal development were identified. The coexistence of recruits and mature individuals throughout the study period suggests that this population presented continuous reproduction.
\end{abstract}

KEY WORDS. Annelida; population ecology; reproductive biology.

Spionidae Grube, 1850 is currently represented by 500 species, grouped into 33 genera (Rocha et al. 2009). In Brazil, 44 species have been recorded within 15 genera (Amaral et al. 2010). Spionids are among the most abundant and frequent animals in soft-bottoms benthic communities (Rouse \& PleijeL 2001, Amaral et al. 2005).

Scolelepis has a worldwide distribution with a total of 80 currently recognized species, from which seven have been recorded along the Brazilian coast (Rосна et al. 2009). Scolelepis goodbodyi (Jones, 1962) is commonly found in the upper limit of the intertidal zone of dissipative beaches and was originally described in the Caribbean region. In Brazil, it was recorded in São Paulo (MacCord \& Amaral 2005) and Rio de Janeiro (Rocha et al. 2009). It can reach up to $12 \mathrm{~mm}$ in length for about 55 setigers (Delgado-Blas 2006). The reproduction is continuous throughout the year (MACCord \& Amaral 2007). Males and females do not exhibit sexual dimorphism, though sex can be easily determined in mature individuals. Males are characterized by whitish spermatocytes and swollen gametogenic setigers when mature, whereas females present yellowish oocytes (MacCord \& Amaral 2007).

Studies on the population dynamics of dominant species in sandy beaches are essential to a better understanding of community dynamics. This study describes the life cycle of $S$. goodbodyi, including recruitment, growth, mortality, and reproductive aspects, in a population inhabiting the intertidal zone of a subtropical Atlantic beach.

\section{MATERIAL AND METHODS}

Manguinhos beach, located in Armação dos Búzios, Rio de Janeiro State, at $22^{\circ} 46^{\prime} 12.17^{\prime \prime}$, long $41^{\circ} 54^{\prime} 52.44^{\prime \prime} \mathrm{W}$, is about $1 \mathrm{~km}$ long, with a gentle slope.

Monthly samplings were performed in the upper level of the intertidal region, during low tides, from June 2009 to May 2010. Ten sampling units were randomly collected from a fixed area of $100 \mathrm{~m}^{2}$ using a hand corer $(25 \mathrm{~cm}$ in length and $10 \mathrm{~cm}$ in diameter). The samples were washed through $0.5 \mathrm{~mm}$ and $0.25 \mathrm{~mm}$ mesh sieves. The animals were anesthetized with $7 \%$ magnesium chloride, subsequently fixed in $4 \%$ formalin, and preserved in $70 \%$ alcohol. Extra sediment samples were collected with the same cylinder (specified above) for the analysis of the granulometry and organic matter. Sediment texture was determined by mechanical sieving according to Suguio (1973); for this analysis was adopted scale of the sediment classification of SHEPARD (1954). Organic matter content was analyzed by sediment calcination in a muffle furnace $\left(450^{\circ} \mathrm{C}\right.$ for four hours).

Microphytobenthic biomass in the sediments was estimated by the determination of pigment concentrations (chlorophyll- $a$ and phaeopigments), by spectrophotometry, from surface sediment samples collected three times monthly with the aid of a syringe with $2 \mathrm{~cm}$ in diameter and inserted $1 \mathrm{~cm}$ deep. The samples were immediately stored in dark plastic containers and frozen. The procedure used is described by STRICKLAND 
$\&$ PARSONs (1972) and the calculations of the chlorophyll- $a$ and phaeophytin concentrations were conducted using the equations of LORENZEN (1967).

Measurements of interstitial water salinity, temperature, and redox potential (Eh) were taken in situ with a portable refractometer, an analog mercury thermometer, and a calibrated Eh electrode model 6A14 HJ, respectively.

The animals were counted and measured in the laboratory. The width of the third setiger (L3S) was used as the morphometric standard measurement because it proved to be the most appropriate indicator of the total body length $\left(n=100, r^{2}\right.$ $=0.714, \mathrm{p}<0.05)$. The L3S was also used for definitions of size classes in the population and for the estimation of growth and mortality parameters. The program FISAT II (GAYANILLO et al. 1997) was used to estimate population parameters. The growth parameters were estimated based in a length-frequency distribution, following the Bhattacharya's method, by separation of normal distribution of data, where each of these normal distributions represents a cohort of global distribution (SPARRE \& VENEMA 1992). The growth curve was adjusted according to the model of Von Bertalanffy (BERTALANFFy 1938), where the cohorts were recognized.

The seasonal Von Bertalanffy equation is applied when there are seasonal fluctuations in growth rate, noting changes in the initial instant in which the individual does not have hypothetically size ( $\mathrm{t} 0$ ). As in the present work, the seasonal variations was not significant, with values close to zero, the routine as used Munro's plot (MunRo's 1982), which does not take into account seasonal variations to estimate growth parameters. The annual mortality rate $(\mathrm{Z})$ was estimated by the capture curve converted in size and using the following formula: $\ln (\mathrm{N})=g$ - $Z^{*} t$; where: $\operatorname{In}(\mathrm{N})=$ number of individuals; $g=$ regression intercept; $Z=$ instant mortality rate; $t=$ estimated age for each cohort. The growth and mortality parameters were estimated using the FISAT II package (GAYANILLo et al. 1997).

The maximum longevity, defined as the time needed by the individual to reach $95 \%$ of the asymptotic length, was calculated by the formula proposed by TAYLOR (1958): $\mathrm{L}_{0.95 \%}=\mathrm{t}_{\mathrm{o}}+$ 2.996/K.

The calculation of the mean density was estimated from the number of individuals obtained monthly and expressed as ind. $\mathrm{m}^{-2}$. The Kruskall-Wallis non-parametric test was used to test the significance of the differences in densities during the studied period.

The observation of the presence and distribution of gametes in the gametogenic setigers were used to estimate the fecundity and reproductive periods in the mature individuals and to separate males, females, and individuals with indeterminate sex. The determination of stages was based on the appearance of the gametes and the number of gametogenic setigers following the classification established by JoYNer (1962) and RichaRds (1970).
The $\chi^{2}$ test was used to determine significance between differences in the sex ratios and between sexually determined and sexually indeterminate individuals.

\section{RESULTS}

The lowest temperature was recorded in July $\left(19^{\circ} \mathrm{C}\right)$ and the highest in March $\left(28^{\circ} \mathrm{C}\right)$ (Tab. I). Redox potential (Eh) presented positive values close to zero (mean of $0.32 \pm 0.03$ ) and the salinity also did not present high variation (mean of $33.5 \pm 1.94$ ).

Table I. Abiotic data in the moment of sampling from the Manguinhos beach, between June 2009 and May 2010.

\begin{tabular}{cccc}
\hline Month/Year & Salinity & Temperature $\left({ }^{\circ} \mathrm{C}\right)$ & Eh $(\mathrm{mV})$ \\
\hline Jun/09 & 35 & 24 & 0.30 \\
Jul/09 & 35 & 19 & 0.32 \\
Aug/09 & 37 & 22 & 0.38 \\
Sept/09 & 34 & 21 & 0.30 \\
Oct/09 & 33 & 25 & 0.33 \\
Nov/09 & 33 & 27 & 0.30 \\
Dec/09 & 35 & 25 & 0.38 \\
Jan/10 & 30 & 26 & 0.33 \\
Feb/10 & 33 & 24 & 0.35 \\
Mar/10 & 30 & 28 & 0.30 \\
Apr/10 & 34 & 26 & 0.30 \\
May/10 & 33 & 25 & 0.33 \\
\hline
\end{tabular}

The mean sediment grain diameter revealed the dominance of medium grain, except in June 2009 and January 2010, when there was course sand. The standard deviation defined the sediments as very poorly sorted (Tab. II).

Table II. Sediments parameters from the Manguinhos beach, between June 2009 and May 2010.

\begin{tabular}{|c|c|c|c|c|}
\hline Months/year & $\begin{array}{c}\text { Areia } \\
(\%)\end{array}$ & $\begin{array}{l}\text { Silte } \\
(\%)\end{array}$ & $\begin{array}{c}\text { Sediment } \\
\text { classification }\end{array}$ & $\begin{array}{c}\text { Grain syze } \\
\text { analyses }\end{array}$ \\
\hline June/2009 & 95.48 & 4.51 & Coarse sand & Very poorly select \\
\hline Juy/2009 & 98.59 & 1.41 & Medium sand & Very poorly select \\
\hline Aug/2009 & 98.92 & 1.07 & Medium sand & Very poorly se \\
\hline Sep/2009 & 99.28 & 0.71 & Medium sand & Very poorly select \\
\hline Oct/2009 & 98.56 & 1.43 & Medium sand & Very poc \\
\hline Nov/2009 & 99.28 & 0.72 & Medium sand & Very poorly select \\
\hline $\mathrm{Dec} / 2009$ & 98.13 & 1.87 & Medium sand & Very poorly select \\
\hline $\operatorname{Jan} / 2010$ & 96.01 & 3.90 & Coarse sand & Very poorly select \\
\hline Feb/2010 & 98.50 & 1.49 & Medium sand & Very poorly select \\
\hline Mar/2010 & 95.66 & 4.33 & Medium sand & Very poorly select \\
\hline Apr/2010 & 98.15 & 1.84 & Medium sand & Very poorly select \\
\hline May/2010 & 98.62 & 1.38 & Medium sand & Very poorly select \\
\hline
\end{tabular}


The mean concentration of organic matter was $9.03 \%$ (mean of $9.03 \pm 6.15$ ) with the highest value in March 2010 $(20.78 \%)$ and the lowest in October 2010 (3.65\%). The concentrations of chlorophyll- $a$ in the surface layer of the sediment peaked in May $2010(24.52 \mu \mathrm{g} / \mathrm{g})$. The concentration of phaeopigments were lower and more variable than the values for chlorophyll- $a$. The higher phaeopigment concentration was observed in the month of April 2010 (3.15 $\mu \mathrm{g} / \mathrm{g})$ (Tab. III).

Table III. Concentrations of chlorophyll- $a(\mathrm{Chl}-a)$ and phaeopigments (Phaeo) in the surface layer of the sediment from the Manguinhos beach, between June 2009 and May 2010.

\begin{tabular}{ccc}
\hline Month/Year & Chl- $a(\mu \mathrm{g} / \mathrm{g})$ & Phaeo $(\mu \mathrm{g} / \mathrm{g})$ \\
\hline Jun/2009 & 17.55 & 2.56 \\
$\mathrm{Jul} / 2009$ & 18.77 & 0.85 \\
Aug/2009 & 17.23 & 1.73 \\
Sep/2009 & 22.61 & 0.33 \\
Oct/2009 & 20.05 & 0.74 \\
Nov/2009 & 18.33 & 1.07 \\
Dec/2009 & 16.09 & 1.70 \\
Jan/2010 & 14.15 & 0.26 \\
Feb/2010 & 12.90 & 0.70 \\
Mar/2010 & 15.57 & 0.67 \\
Apr/2010 & 16.89 & 3.15 \\
May/2010 & 24.52 & 0.65 \\
\hline
\end{tabular}

A total of 9,242 individuals were collected. The highest abundances were recorded in June and September 2009 (1,222 and 919 individuals, respectively) and the lowest in August 2009 (539 individuals). No individuals were found in July. High densities of the polychaete Magelona papillicornis (Müller, 1858) were observed only in July. Capitella cf. capitata (Fabricius, 1780), co-occurred with $S$. goodbodyi during the whole study period. The density of $S$. goodbodyi showed small variation during the studied period, with an annual mean of 16.38 ind $\mathrm{m}^{-2}$. The high-

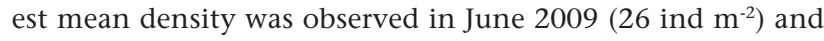
the lowest in July $2009\left(0\right.$ ind $\left.\mathrm{m}^{-2}\right)$ (Fig. 1). The density values did not show significant differences (Kruskal-Wallis $\mathrm{p}>0.05$ ).

A total of 2,919 males (31.6\%), 2,307 females (24.9\%), and 4,016 sexually indeterminate individuals (43.4\%) were analyzed. The males prevailed over the females in all months. A significant difference was observed between sexually determinate and indeterminate individuals $\left(\chi^{2}=158.4, \mathrm{df}=1\right.$, $\mathrm{p}<0.01)$, and between males and females $\left(\chi^{2}=71.6, \mathrm{df}=1\right.$, $\mathrm{p}<0.01)$. The sexually indeterminate individuals were more abundant between June and September of 2009. The sexually determinate individuals presented the highest proportions in the other months and in December 2009 the highest frequency (90.4\%) (Fig. 2). Among individuals with indeterminate sex, the highest proportion was among the recruits, followed by those considered sexually immature (L3S \# $0.50 \mathrm{~mm}$ ) (Fig. 3).

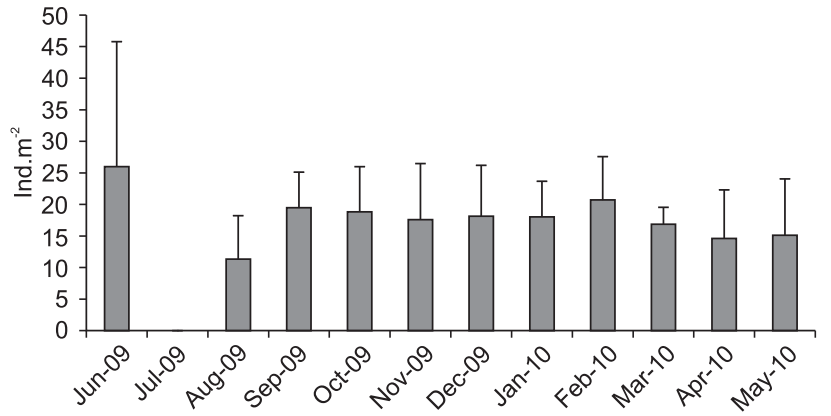

Figure 1. Temporal variation of the density of Scolelepis goodbodyi (monthly means), from June 2009 to May 2010. Note: vertical bars represent the standard error.

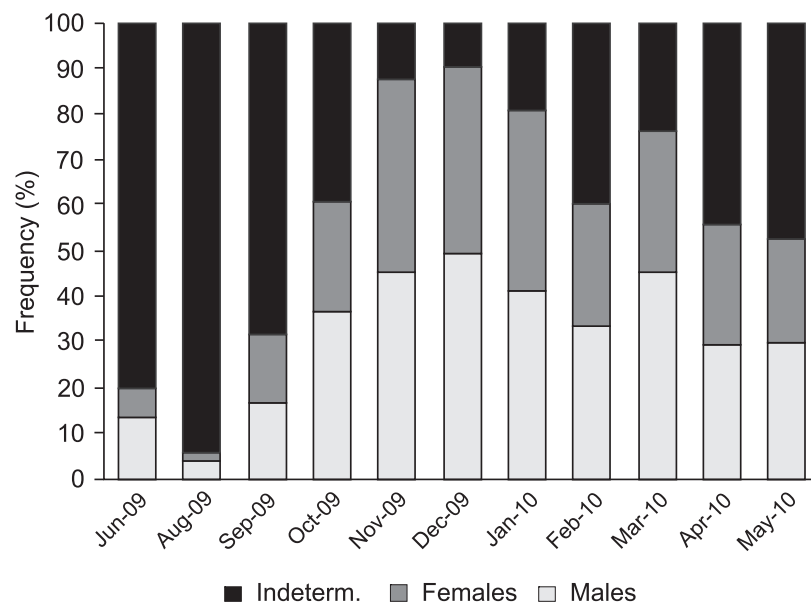

Figure 2. Distribution frequency of indeterminate sex, females, and males of Scolelepis goodbodyi during the sampling period.

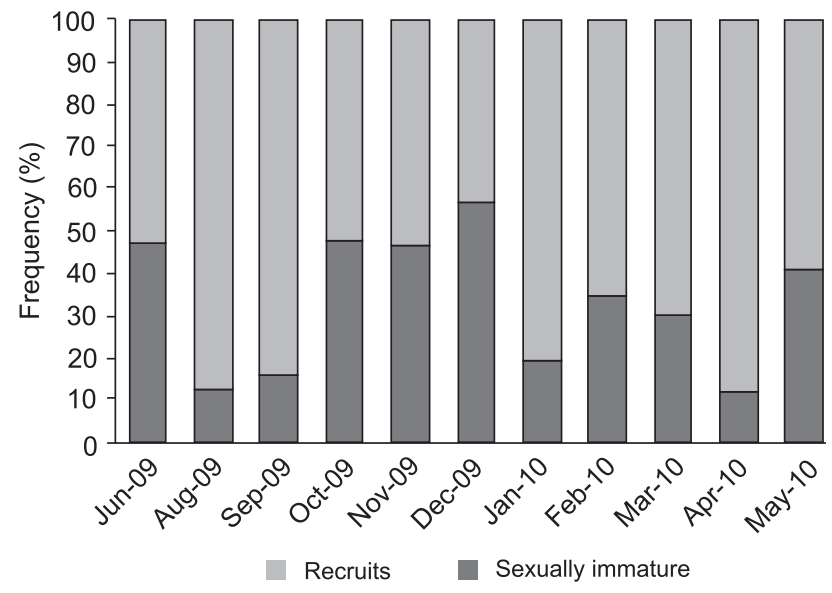

Figure 3. Distribution frequency of sexually indeterminate (sexually immature and recruits) Scolelepis goodbodyi individuals during the sampling period. 
The first sexual maturation occurred in individuals measuring $0.55 \mathrm{~mm}$ (L3S) and the first gametogenic setiger of $S$. goodbodyi occurred from the $20^{\text {th }}$ segment. This pattern occurred regardless of the size of the individuals. The maximum number of filled setigers observed was 37 .

Five stages of gonadal development were recorded among the 5,226 analyzed mature individuals (Tab. IV). The stage VI (gonads recovery) was not identified in this study because it did not show visible gametes and this classification is only possible from histological observations. Stage IV (mature) was the most frequent (Fig. 4), representing $58.17 \%$ of the individuals, followed by stage $\mathrm{V}$ (partial release of gametes), with a total of $26.57 \%$. The other stages (I, II, and III) were less represented and the least frequent was stage I, with a total of only $0.57 \%$. The males prevailed in stages II and III and were exclusive in stage I. The two sexes were well represented in the final stages of gonadal development (IV and V), although males were prevalent.

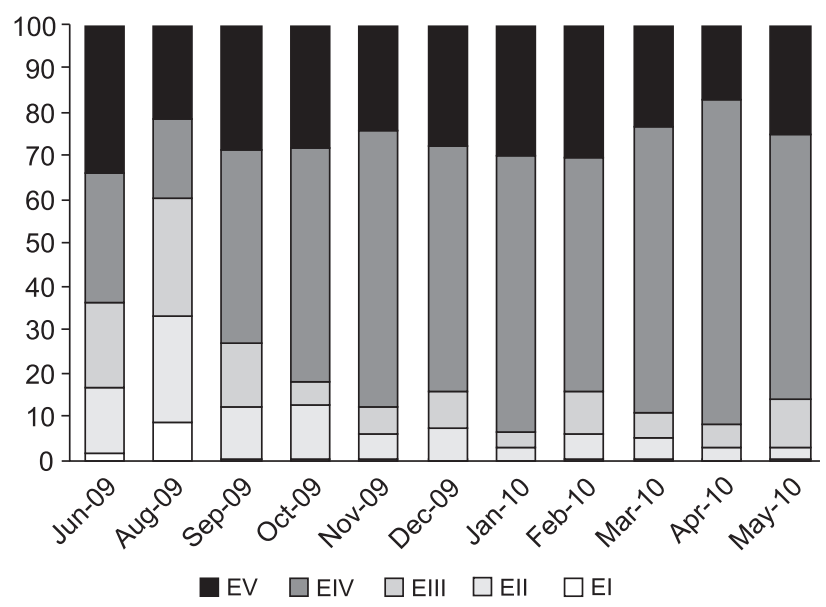

Figure 4. Distribution e frequency of gonadal development stages of Scolelepis goodbodyi. Stage I: initial development; stage II: proliferation; stage III: immature; stage IV: mature; stage V: partial release of gametes.
The sizes varied from $0.15 \mathrm{~mm}$ to $1.0 \mathrm{~mm}$ and the most frequent were between $0.55 \mathrm{~mm}$ and $0.75 \mathrm{~mm}$ (Fig. 5). The population showed a bimodal frequency distribution in 7 of

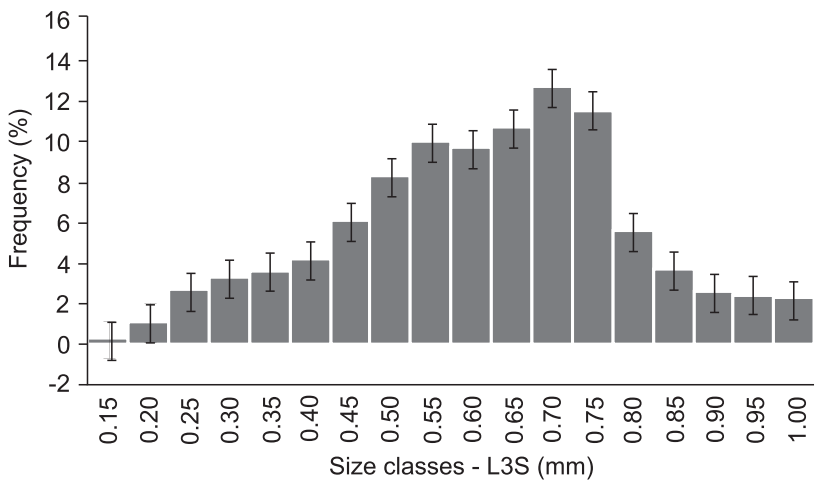

Figure 5. Distribution frequency of size classes based on the width of $3^{\text {rd }}$ setiger (L3S) of 9,242 individuals from Manguinhos beach during a twelve-month period. Note: vertical bars represent the standard error.

the 12 analyzed months (except July) (Fig. 6). The population of $S$. goodbodyi presented constant recruitment throughout the studied period (except in July 2009) with higher number between June and September 2009 (Fig. 7). In the following months after that and until December 2009 the recruitment was reduced. However, it increased after January. Two cohorts were identified in the population through the analysis of frequency distributions (Fig. 6). Both began during the coldest period (June 2009); cohort 1 with individuals from the smaller size classes who grew up and remained in the population until May 2010. The analysis shows that the population of this cohort probably extended to the subsequent months, which could not be proven because of the end of sampling. The individuals in cohort 2 belonged to the larger size classes and remained in the population until March 2010, when mortality was evident.

Table IV. Classification of the gonadal development stages, modified from JOYNER (1962) and RICHARDS (1970). Note: characteristics registered only in this study are shown in bold. (GS) Gametogenic setiger.

\begin{tabular}{cccll}
\hline Stages & Gametogenic setiger & $\begin{array}{c}\text { Total number of } \\
\text { gametogenic setiger }\end{array}$ & \multicolumn{1}{c}{ Male setigers } & \multicolumn{1}{c}{ Female setigers } \\
\hline $\begin{array}{l}\text { Stage I } \\
\text { Stage II }\end{array}$ & 23 & $1-4$ & $\begin{array}{l}\text { Slightly whitish } \\
\text { Slightly whitish, mixed } \\
\text { with natural body color }\end{array}$ & $\begin{array}{l}\text { Dispersed oocytes in each } \\
\text { setiger, whitish } \\
\text { Densely packed in parapodia, } \\
\text { yellowish } \\
\text { Stage III }\end{array}$ \\
Stage IV & 23 & $5-9$ & Milky white & $\begin{array}{l}\text { Densely packed in parapodia, } \\
\text { yellowish } \\
\text { Dispersed oocytes in each } \\
\text { setiger, yellowish }\end{array}$ \\
Stage V & $\begin{array}{l}23 \text { (empty setigers } \\
\text { Stage VI }\end{array}$ & $>9$ & Milky white & Milky white \\
\hline
\end{tabular}



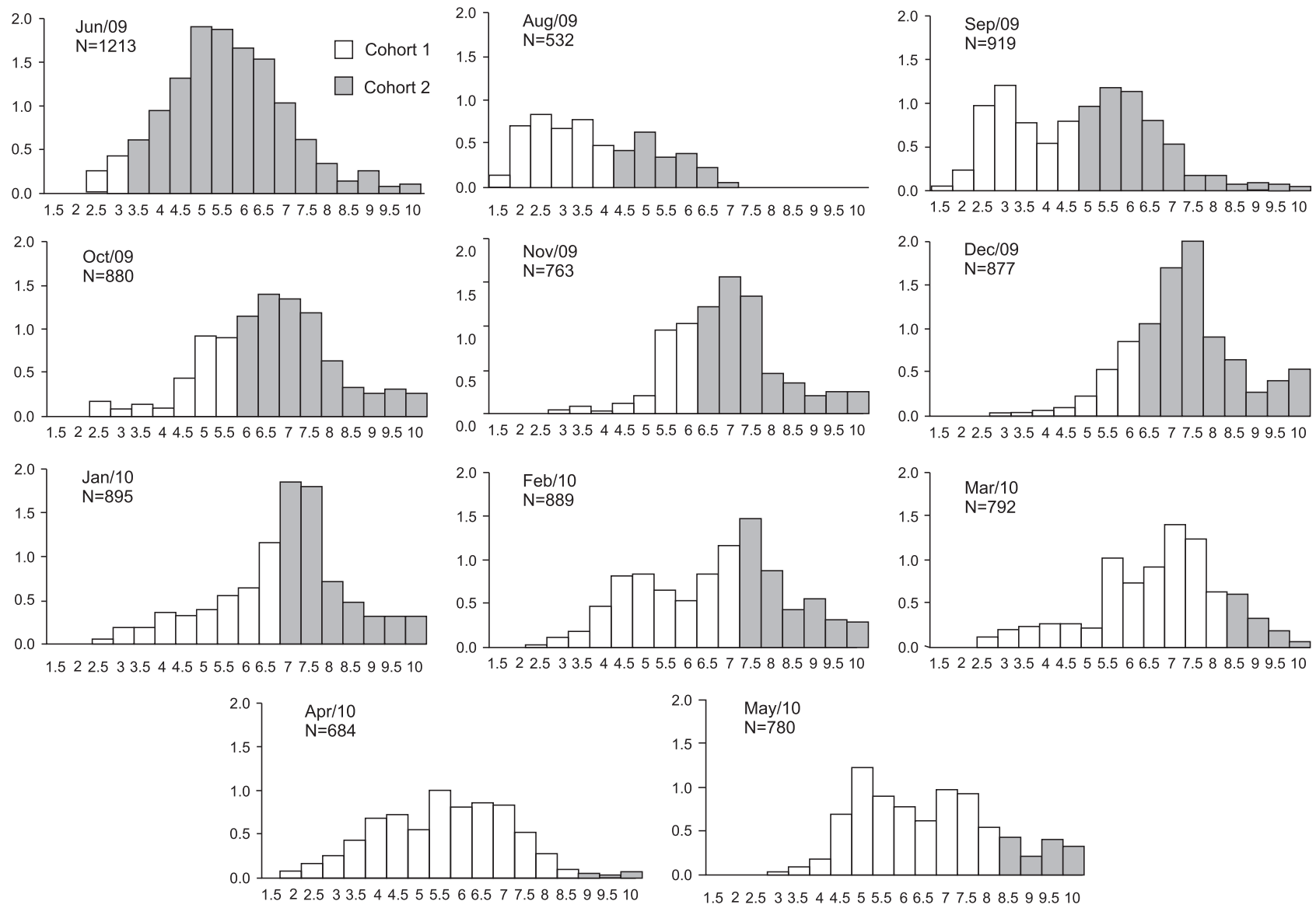

Figure 6. Frequency histograms of size classes of L3S (mm) of Scolelepis goodbodyi between June/09 and May/10, showing two distinct cohorts.

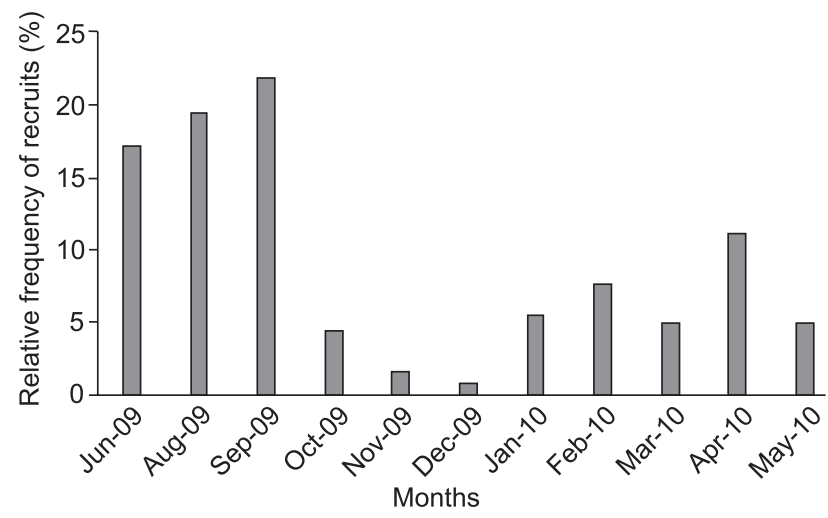

Figure 7. Relative frequency of recruits over 12 months (2009/2010).

The asymptotic size ( $\mathrm{L} \infty$ ) of $S$. goodbodyi was $1.23 \mathrm{~mm}$. The rate of 1.2 was recorded for the growth constant $(\mathrm{K})$. The estimated longevity for the population was of 2.5 years, and the mortality rate (Z) was 0.73 (Fig. 8).

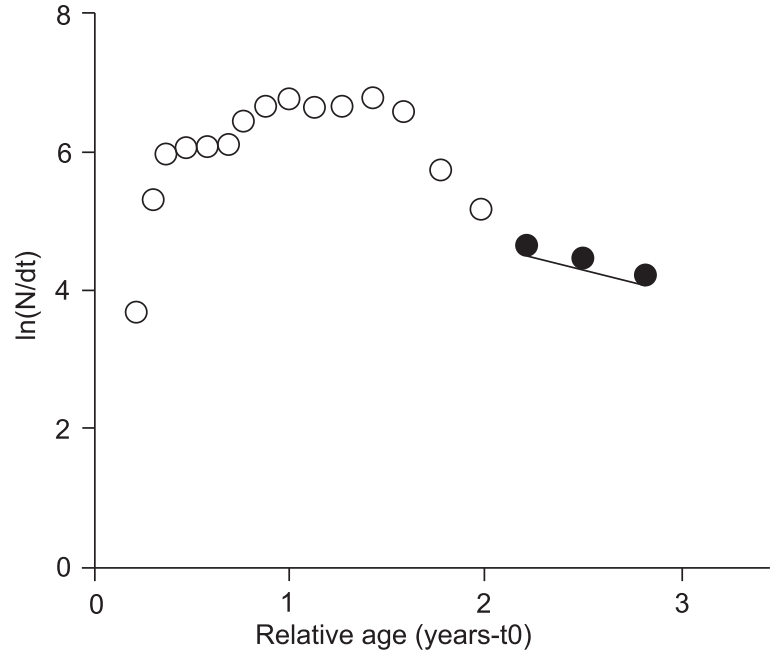

Figure 8. Capture curve converted by the Scolelepis goodbodyi population size. Black circles represent the monthly values used for the calculation of the mortality rate. 


\section{DISCUSSION}

The absence of $S$. goodbodyi in July 2009 coincided with the lowest recorded temperature, but there was no correlation of average densities with temperature during the study period (Fig. 9). The organic matter concentrations in the sediment from the Manguinhos beach showed an annual mean of $9.03 \%$ and were relatively high and constant when compared to the results obtained by Rizzo \& Amaral (2000) in the intertidal zone at Engenho d'Água beach. Deposit-feeders, as is the case of several species of polychaetes, as $S$. goodbodyi, are found, in general, in high densities in areas with an increased concentration of nutrients (Lopez \& Levinton 1987). The high densities of $S$. goodbodyi recorded throughout the study may be related to the quantity of food resources existing in the Manguinhos beach. Surugiu (2005) and Surugiu \& Feuteun (2008) showed that depositivorous polychaetes living in the sediment surface, as is the case of the spionids, could reduce the accumulated organic matter in the sediment, by transforming it and incorporating it into their own biomass.

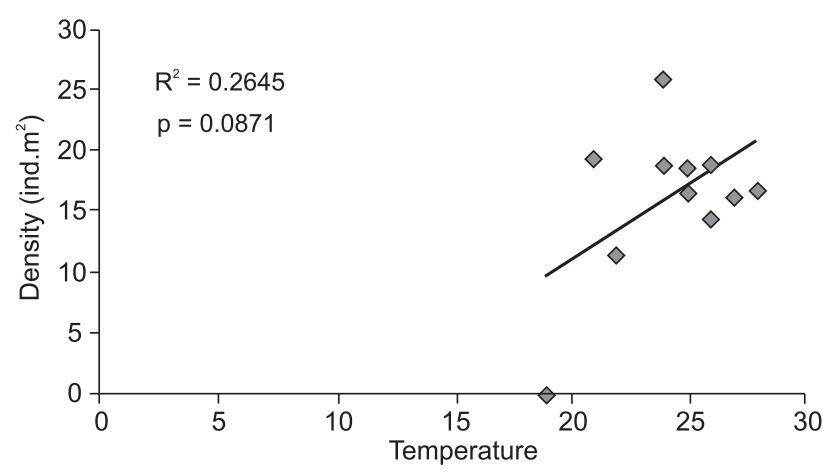

Figure 9. Temporal variation of temperature and population mean density (ind. $\mathrm{m}^{-2}$ ) of Scolelepis goodbodyi during the studied months.

The local population of $S$. goodbodyi co-existed with a population of $C$. $c f$. capitata. This contradicts previous studies which have suggested negative interactions among spionids and capitellids, due to competition for space and food (Whitlatch \& Zajac 1985, Sardá et al. 1995). Conversely, the high densities of $M$. papillicornis, also a deposit-feeder, in July 2009 may have affected S. goodbodyi. Bioturbation caused by this magelonid may also have prevented the larval settlement and recruitment, as previously suggested by Woodin (1991), Desroy et al. (1998) and Hentschel (2004).

The local population of $S$. goodbodyi presented continuous reproduction. Juveniles were present during the whole period, but were more frequent in the colder months probably due to spawning after the hottest period when reproductive activity is higher. Sexually determinated individuals were prevalent in the warmer months. The same pattern was previoulsy recognized for other spionid species (Zajac 1991, Speybroeck et al. 2007). In general, temperature increases can be a stimulus for spawning in polychaetes, though temperature decreases may have a similar effect (ARIAs \& DraKe 1995). The continuous reproduction observed in this study was also reported in a population of Scolelepis goodbodyi from Barequeçaba Beach, in São Paulo (MacCord \& Amaral 2007). This pattern is probably a tendency in siponid species from subtropical or warmer regions with high food availability (SANTos 1994, Souza \& Borzone 2000). High concentrations of organic matter and chlorophyll- $a$ were always recorded, which may have favored the locally continuous reproduction of $S$. goodbodyi.

Regardless of the presence of mature females throughout the study period, mature males were always more abundant. This is a somewhat unexpected pattern, since females need to release large amount of oocytes to ensure reproductive success, whereas the sperm contained in just a few setigers in males may be sufficient to fertilize dozens of oocytes.

Five stages of gonadal development, based on the external morphology of the gametogenic setigers, were observed. The constant presence of individuals in the final stages of development (IV and V) together with sexually immature individuals $\left({ }_{s} 0.50 \mathrm{~mm}\right)$ suggests the prevalence of a continuous process of reproduction and that the local population can grow fast, as also suggested by the growth constant $(K=1,2)$. Spionids do not normally limit their reproductive activity to one seasonal period (Blake \& Arnofsky 1999). Giangrande (1997) suggested that smaller individuals tend to reproduce continuously, since they do not have enough space to produce a large number of eggs.

The observed developmental stages corresponded by and large to those described by Joyner (1962) and Richards (1970), except in the gametogenic setigers of males in stage I (early development) and $\mathrm{V}$ (partial release of gametes). The setigers presented a slight whitish coloration in stage I and in stage V; the male setigers did not present a coloration similar to the body coloration as described by these authors (see Tab. IV). The position of the first gametogenic setiger in mature individuals occurred from the $20^{\text {th }}$ segment, regardless of the size and sex of the individuals. MACCord \& AmaraL (2005) observed the same pattern in the $S$. goodbodyi at Barequeçaba beach. This characteristic may vary in other species of spionids, both in relation to the position of the first gametogenic setiger or the total number of gametogenic setigers (Yокоуама 1990, ZajaC 1991). The maximum number of filled setigers was 37 , suggesting that, at this stage, the individuals begin to lose their gametes (stage $\mathrm{V}$ ) during spawning.

The estimates of the growth parameters of $S$. goobodyi, obtained through the Bhattacharya method, showed relatively high growth (1.2) and a low mortality rate (0.73) when compared with rates estimated for other spionid species (Tab. V). These variations can be explained by the reproductive plasticity among spionids, that reflects their many fertilization mecha- 
Tab Table V. Growth parameters of different Spionidae species. L $\infty$ asymptotic length; K growth constant; Z mortality rate.

\begin{tabular}{ccccll}
\hline \multicolumn{1}{c}{ Species } & $\mathrm{L} \infty(\mathrm{mm})$ & $\mathrm{K}$ & $\mathrm{Z}$ & \multicolumn{1}{c}{ Author } & \multicolumn{1}{c}{ Localities } \\
\hline Scolelepis squamata & 2.48 & 0.51 & 4.08 & SPREYBROECK et al. (2007) & Belgian sandy beaches \\
Scolelepis goodbodyi & 1.23 & 1.20 & 0.73 & This study & Manguinhos beach, Brazil \\
Scolelepis gaucha & 0.83 & 2.50 & 11.35 & SANTOS (1994) & Patos Lagoon, Brazil \\
Scolelepis squamata & 0.70 & 2.60 & 2.52 & SouZA \& BORZONE (2000) & Atami beach, Brazil \\
\hline
\end{tabular}

nisms (Rouse \& Plejel 2001), and by the subtropical location, which may affect the life cycle of polychaetes (OMENA \& AMARAL 2000). The relative stability of environmental conditions at Manguinhos beach, as well as the high availability of food resources, may have favored the growth in population of Scolelepis goodbodyi. Studies by Allen \& Moore (1987) and Hutchings (1998) suggested that the stability of environment factors is the main factor structuring communities of sandy beaches.

Two cohorts were identified. A similar pattern was reported for other spionids, including Scolelepis, with the emergence of two cohorts and a long reproductive period (SANTOS 1994, Souza \& Borzone 2000, Bolam 2004, Garcia-Arberas \& Rallo 2004). The individuals in cohort 1 (with smaller sizes) showed rapid growth $(\mathrm{K}=1.2)$ and were incorporated to the adult population in the following months. These individuals remained in the population until May 2010 demonstrating their successful settlement. They probably remained in this population for longer periods because they were still present in May 2010, however, no further conclusions can be drawn because the sampling were interrupted after that month.

The second cohort was relatively short in comparison with the first one and evidente up to March 2010, when there as a decrease in the population. The arrival of new recruits in the population, starting from January, may have been the result of a new spawning, but the production of additional cohorts was not identified during the studied period.

In summary, mature adults and large numbers of recruits were always found simultaneously in the population. The estimated longevity was high when compared with similar studies on spionids. The long lifespan combined with high densities and low mortality rates may explain the local persistence of $S$. goodbodyi in Manguinho's beach.

\section{LITERATURED CITED}

Allen, P.L. \& J.J. Moore. 1987. Invertebrate macrofauna as potential indicators of sandy beach instability. Estuarine, Coast and Shelf Science 24: 109-125.

Amaral, C.A.Z.; A.E. Rizzo \& E.P. Arruda. 2005. Manual de identificação dos invertebrados marinhos da região SudesteSul do Brasil. São Paulo: Universidade de São Paulo, I +287p.

Amaral, C.A.Z.; S.A.H. Nallin \& T. M. Steiner. 2010. Catálogo das espécies dos Annelida Polychaeta da Costa Brasileira. Available online at: http://www.ib.unicamp.br/desta- ques/biota/bentos_marinho/prod_cien/texto_poli.pdf [Acessed: 15/X/2010].

ARIAS, A.M. \& P. DraKE.1995. Structure and production of the benthic macroinvertebrate community in a shallow lagoon in the Bay of Cadiz. Marine Ecology Progress Series 115: 151-167.

Bertalanffy, L.V. 1938. A quantitative theory of organic growth (inquiries on growth laws II). Human Biology 10: 181-213.

Bhattacharya, C.G. 1967. A simple method of resolution of a distribution into Gaussian components. Biometrics 23: 115-135.

Blake, J.A. \& P.L. ARnofsky. 1999. Reproduction and development of the spioniform Polychaeta with application to systematic and phylogeny. Hidrobiology 402: 57-106.

Bolam, S.G. 2004. Population structure and reproductive biology of Pygospio elegans (Polychaeta: Spionidae) on intertidal sandflat, Firth of Forth, Scotland. Invertebrate Biology 123 (3): 260-268.

Delgado-Blas, V.H. 2006. Partial revision of Scolelepis (Polychaeta:Spionidae) from the Grand Caribbean region, with the description of two new species and a key to species recorded in the area. Contributions to Zoology 75 (1/2): 75-97.

Desroy, N.; C. Retière \& E. Thiébaut. 1998. Infaunal predation regulates Nephtys hombergii (Savigny) on recruits of Nereis diversicolor (O. F. Müller). Journal of Experimental Marine Biology and Ecology 228: 257-272.

FolK, R.L. \& W.C. WARD. 1957. Brazos river bar: a study of significant of grain size parameters. Journal Sedimentary Petrology 24: 3-26.

Garcia-Arberas, L. \& A. Rallo. 2004. Population dynamics and production of Streblospio benedicti (Polychaeta) in a nonpolluted estuary on the Basque coast (Gulf of Biscay). Scientia Marina 68 (2): 193-203.

Gayanilo, F.C.J.R.; P. Sparke \& D. Pauly. 1997. FAO_ICLAR stock assessment tools. (FISAT). Reference manual. Rome, FAO Computerized Series (Fisheries), VIII+262p.

Giangrande, A. 1997. Polychaete reproductive patterns, life cycles and life histories: an overview. Oceanography and Marine Biology 35: 323-386.

Hentschel, B.T. 2004. Sediment resuspension and boundary layer flow dramatically increase the growth rates of interfacefeeding spionid polychaetes. Journal of Marine Systems 49: 209-224.

HUTCHINGS, P. 1998. Biodiversity and functioning of polychaetes in benthic sediments. Biodiversity and Conservation 7: 1133-1145. 
Joyner, A. 1962. Reproduction and larval life of Nerine cirratulus (Delle Chiaje) family Spionidae. Proceedings of the Zoology Society London 138: 655-666.

Lorenzen, C.J. 1967. Determination of chlorophyll and pheopigments: spectro-photometric equations. Limnology and Oceanography 12: 343-346.

Lopez, G.R. \& J.S. Levinton. 1987. Ecology of deposit-feeding animals in marine sediments. The Quarterly Review of Biology 62 (3): 235-260.

Maccord, F.S. \& A.C.Z. Amaral. 2005. Morphometric analyses of two species of Scolelepis (Polychaeta; Spionidae). Journal of the Marine Biological Association of the United Kingdom 85: 829-831.

MACCORD, F.S. \& A.C.Z. Amaral. 2007. The reproductive cycle of Scolelepis goodbodyi (Polychaeta: Spionidae). Marine Biology 151: 1009-1020.

MunRo, J.L. 1982. Estimation of the parameters of the von Bertalanffy growth equation from recapture data at variable time intervals. Conseil International pour I'Exploration de la Mer 40: 199-200.

Omena, E.P. \& A.C.Z. Amaral. 2000. Population dynamics and secondary production of Laeonereis acuta (Treadwell, 1923) (Nereididae: polychaeta). Bulletin of Marine Science 67 (1): 421-431.

RICHARDS, S.L. 1970. Spawning and reproductive morphology of Scolelepis squamata (Spionidae: Polychaeta). Canadian Journal of Zoology 48: 1369-1379.

Rizzo, A.E. \& A.C.Z. Amaral. 2000. Temporal variation of annelids in the intertidal zone of beaches of the São Sebastião Channel, southern Brazil. Journal of Marine Biology Assessment 80: 1007-1017.

Rocha, M.B.; V. Radashevsk \& P.C. Paiva. 2009. Espécies de Scolelepis (Polychaeta: Spionidae) de praias do estado do Rio de Janeiro, Brasil. Biota Neotropica 9 (4): 101-108.

Rouse, G.W. \& F. Pleijel. 2001. Polychaetes. Oxford, University Press, I +352p.

SAnTos, P.J.P. 1994. Population dynamics and production of Scolelepis gaucha (Polychaeta: Spionidae) on the sandy beaches of Southern Brazil. Marine Ecology Progress Series 110: 159-165.

Sardá, R.; I. Valiela \& K. Foreman. 1995. Life cycle, demography and production of Marenzelleria viridis in a salt marsh of southern New England. Journal of Marine Biology Assessment 75: 725-738.

SHEPARD, F.P. 1954. Nomenclature based on sand-silt-clay ratios. Journal Sedimentary Petrology 24: 151-158.
SouzA, J.R.B. \& C.A. Borzone. 2000. Population dynamics and secondary production of Scolelepis squamata (Polychaeta: Spionidae) in an exposed sandy beach, Southern Brazil. Bulletin of Marine Science 67: 221-233.

Sparre, P.; S.C. Venema. 1997. Introdução à avaliação de mananciais peixes tropicais. Parte I: Manual. FAO Documento técnico sobre as pescas 306: 404p.

Speybroeck, J.; L. Alsteens; M. Vincx; S. Degraer. 2007. Understanding the life of a sandy beach polychaetes of functional importance - Scolelepis squamata (Polychaeta: Spionidae) on Belgian sandy beaches (northeastern Atlantic, North Sea). Estuarine, Coastal and Shelf Science 74: 109-118.

Strickland, J.D.H. \& T.R. Parson. 1972. A practical handbook of seawater analysis. Bulletin Fisheries Research Board of Canada 167: 1-205.

SUGUIO, K. 1973. Introdução a sedimentologia. São Paulo, Edgar Blücher, I+318p.

Surugiu, V. 2005. The use of poychaetes as indicators of eutrophication and organic enrichment of coastal waters: a study case - Romanian Black Sea Coast. Analete Stiintifice ale Universitatii "Al. I. Cusa" Iasi, s. Biologie animala 51: 55-62. Available online at: http://www.bio.uaic.ro/ publicatii/anale_zoologie/issue/2005/10-V_Surugiu.pdf [Accessed: 10/V/2012]

Surugiu, V. \& M. Feunteun. 2008. The structure and distribution of polychaete populations influenced by sewage from the Romanian Coast of the Black Sea. Analete Stiintifice ale Universitatii “Al. I. Cusa" Iasi, s. Biologie animala 54: 177-184. Available online at: http://www.bio.uaic.ro/ publicatii/anale_zoologie/issue/2008/22-2008.pdf [Accessed: 10/V/2012]

TAYLOR, C.C. 1958. Cod growth and temperature. Journal Du Conseil International pour I'Exploration de La mer 23: 366-370.

WhitLach, R.B. \& R.N. Zajac. 1985. Biotic interactions among estuarine infaunal opportunistic species. Marine Ecology Progress Series 21: 299-311.

Woodin, S.A. 1991. Recruitment of infauna: positive or negative cues? American Zoologist 31: 797-807.

Yoкоуама, H. 1990. Life history and population structure of the Spionid polychaete Paraprionospio sp. (form A). Journal of Experimental Marine Biology and Ecology 144: 125-143.

ZajaC, R.N. 1991. Population ecology of Polydora ligni (Polychaeta: Spionidae). I. Seasonal variation in population characteristics and reproductive activity. Marine Ecology Progress Series 77: 197-206.

Submitted: 18.XI.2011; Accepted: 14.V.2012.

Editorial responsibility: Paulo da Cunha Lana 